\title{
Identifikasi Jamur Pada Tukik Lepidochelys olivacea, Eschscholtz, 1829 (Reptilia : Cheloniidae) Di Turtle Conservation And Education Center Bali
}

\author{
Ika Ayuningtyas*, Edi Wibowo Kushartono, Sri Redjeki \\ Departemen IImu Kelautan, Fakultas Perikanan dan Ilmu Kelautan, Universitas Diponegoro \\ JI. Prof. H. Soedarto S.H, Tembalang,Semarang, Jawa Tengah 50275 Indonesia \\ ${ }^{*}$ Corresponding author, e-mail: ikaayuningtyas33@gmail.com
}

\begin{abstract}
ABSTRAK : Penyu merupakan vertebrata laut yang termasuk kedalam kategori Appendix 1 yang artinya dilarang diperdagangkan secara internasional. Selain itu penyu salah satu hewan yang paling terancam populasinya secara langsung maupun tidak langsung. Kematian tukik penyu disebabkan oleh berbagai faktor, diantaranya kerusakan habitat alami, pencemaran laut, serangan predator dan perburuan daging maupun telurnya untuk kepentingan komersial. Selain itu, menurunnya jumlah populasi penyu juga disebabkan dari infeksi jamur. Adanya jamur juga menjadi masalah di TCEC (Turtle Conservation and Education Center) yang menyebabkan tingginya tingkat kematian tukik dari penyu lekang (Lepidochelys olivacea). Maka dari itu dengan mengetahui jenis jamur yang ditemukan dapat dilakukan pengobatan serta pencegahan sesuai jamur yang menginfeksi. Tujuan dari penelitian ini adalah untuk mengidentifikasi jamur yang ditemukan pada bagian tubuh penyu lekang (L. olivacea) dan cangkang telur penyu gagal menetas. Sampel tukik dari penyu lekang berumur $10-14$ hari didapatkan dari penangkaran penyu TCEC Bali. Sampel yang sudah diambil kemudian diswab pada media PDA dan diinkubasi selama 7 hari. Setelah itu dilakukan purifikasi hingga didapatkan koloni murni. Tahap selanjutnya yaitu dilakukannya identifikasi genus secara makroskopis dan mikroskopis pada perbesaran 40x dan 100x. Hasil penelitian memperlihatkan bahwa dari 10 sampel jamur yang diambil dari beberapa bagian tubuh penyu seperti pada mata, kaki, leher dan karapas dan cangkang telur gagal menetas saat sampling, didapatkan 15 isolat koloni jamur. Dari 15 isolat tersebut, ditemukan 5 genus Aspergillus sp, 5 genus Fusarium sp, 3 genus Pytophthora sp dan 1 isolat Trichoderma $s p$. Pada bagian tubuh jamur yang paling banyak ditemukan yaitu pada bagian leher sebanyak 4 koloni dan masing-masing jenis jamur bisa ditemukan pada bagian leher. Jenis jamur yang paling banyak ditemukan pada cangkang telur penyu lekang yang gagal menetas yaitu jamur Aspergillus $s p$ yang masing - masing memiliki bercak kuning pada cangkang telur. Selain dari cangkang telur yang memiliki bercak kuning didapatkan juga dari cangkang telur yang melunak.
\end{abstract}

Kata Kunci : Penyu Lekang, Cangkang Telur, Fusarium, Pytophthora, Trichoderma

\section{The Identification of Fungi in Lepidochelys olivacea, Eschscholtz, 1829 (Reptilia: Cheloniidae) At the Turtle Conservation and Education Center in Bali}

ABSTRACT : Turtle is a marine vertebrata that belongs to Appendix 1 category which means it is prohibited to be traded internationally. In addition there is a sea turtle one of animals that are most under threat its population is set directly or indirectly. The death of hatchlings sea turtle was caused by various factors, including natural habitat destruction, marine pollution, predatory attacks and the hunting of meat and eggs for commercial purposes. In addition, the declining number of turtle populations is also caused by fungal infections. The presence of fungi is also a problem in TCEC which causes high mortality rates of turtles (Lepidochelys olivacea). Therefore, by knowing the type of fungus that can be found to be treated as well as prevention of appropriate fungi that infect. The purpose of this study was to identify the fungus found in the turtle body part ( $L$. olivacea) and the turtle eggshell failed to hatch. The turtle samples from turtles aged 10-14 days were obtained from TCEC Bali turtle breeding. Samples were taken later in swabbing on PDA media and incubated for 7 days. After that purification to get a pure colony. The next stage is the identification of the genus in macroscopic and microscopic at 40x and 100x magnification. The results showed that from 10 samples of fungus taken from some parts of sea turtle body such as on eyes, feet, neck and carapace, and eggshell failed to hatch during sampling, 15 isolates of fungal colonies were found. Of the 15 isolates, found 5 genera of Aspergillus sp, 5 genus of 
Fusarium sp, 3 genus of Pytophthora sp and 1 isolate of Trichoderma sp. In the body of the fungus is most commonly found in the neck as much as 4 colonies and each type of fungus can be found on the neck. The most common types of fungus found in eggshell shells that fail to hatch are the Aspergillus sp fungus, each of which has yellow spots on the eggshell. Apart from the eggshell that has yellow spots it is also obtained from the softened eggshell.

Keywords : Olive Ridley, Eggshell, Fusarium, Pytophthora, Trichoderma

\section{PENDAHULUAN}

Penyu merupakan reptil yang hidup di laut serta mampu bermigrasi dalam jarak yang jauh di sepanjang kawasan Samudera Hindia, Samudera Pasifik dan Asia Tenggara. Keberadaan penyu telah lama terancam, baik oleh faktor kegiatan manusia yang membahayakan populasinya secara langsung maupun tidak langsung. Seluruh spesies penyu laut di dunia telah ditetapkan sebagai spesies yang terancam punah (Endangered Species) dan dicantumkan dalam Data Buku Merah (Red Book Data) oleh IUCN (The International Union for Conservation of Nature and Natural Resource). Berdasarkan konvensi CITES (The Convention on International Trade in Endangered Species of Wild Fauna and Flora), penyu dimasukkan dalam Appendix I yang artinya dilarang diperdagangkan secara Internasional. Kondisi inilah yang menyebabkan semua jenis penyu di Indonesia diberikan status dilindungi oleh Negara sebagaimana tertuang dalam PP Nomor 7 Tahun 1999 tentang "Pengawetan Jenis Tumbuhan dan Satwa". Akan tetapi pemberian status perlindungan saja tidak cukup untuk memulihkan atau setidaknya mempertahankan populasi penyu di Indonesia. Oleh karena itu dibutuhkan tindakan nyata dalam melakukan pengelolaan konservasi penyu yang komprehensif, sistematis dan terukur.

Indonesia memiliki enam dari tujuh jenis penyu yang hidup di dunia dan Bali merupakan salah satu provinsi di Indonesia yang ditetapkan sebagai kawasan konservasi penyu, tepatnya di TCEC Bali. TCEC merupakan balai penangkaran penyu yang digunakan untuk mempelajari siklus kehidupan penyu atau apapun yang berhubungan dengan penyu.

Menurut Javier et al. (2010), kematian tukik disebabkan oleh berbagai faktor, diantaranya kerusakan habitat alami, pencemaran laut, serangan predator dan perburuan daging maupun telurnya untuk kepentingan komersial. Selain itu, menurunnya jumlah populasi penyu juga disebabkan dari kematian penyu diantaranya ektoparasit (lintah) dan endoparasit (nematoda dan trematoda) (Greiner, 2003), penyakit virus (seperti fibropapilloma yaitu penyakit melemahkan atau mematikan bagi hewan ini) (Higgins, 2003) penyakit pernapasan, dan infeksi jamur (Phillott dan Parmenter, 2001; Higgins, 2003; Sarmiento-Ramirez, et al., 2010).

Beberapa jenis jamur yang teridentifikasi pada kulit dan karapas penyu lekang diantaranya berasal dari genus Fusarium solani dan Fusarium oxysporum yang ditemukan pada penyu belimbing di Kolombia (Phillott et al., 2002). Aspergillus sp, Fusarium sp, Penicillium sp dan Chrysosporium sp ditemukan karapas penyu tempayan di Turki (Guclu et al., 2010).

Jamur mengakibatkan penurunan populasi penyu di dunia. Jamur ini biasanya muncul pada keadaan yang lembab saat telur yang masih didalam pasir yang hangat dan memiliki kelembapan yang tinggi. Phillott dan Parmenter (2001) dan Sarmiento-Ramirez et al. (2010) menyatakan bahwa jamur berkembang dalam sarang dengan kondisi sarang pasir yang padat dan menyebabkan telur menjadi membusuk dan embrio tidak berkembang. Dari beberapa jamur yang ditemukan bersifat pathogen dan antagonis, jamur ini menyebabkan penyakit dan mengganggu fungsi sel normal oleh racun serta memproduksi enzim yang dapat mengganggu atau merusak sel-sel dalam telur.

Adanya jamur yang menginfeksi tukik penyu lekang dan penyu lekang dewasa juga menjadi masalah di penangkaran penyu TCEC Bali. Dengan mengetahui jenis jamur yang menginfeksi tukik penyu lekang, maka dapat dilakukan pengobatan dan pencegahan sesuai dengan jenis jamur yang menginfeksi penyu tersebut. Hal inilah yang mendasari peneliti untuk melakukan penelitian mengenai jenis- jenis jamur pada penyu dan cangkang telur penyu gagal menetas.

Penelitian ini bertujuan untuk mengidentifikasi jamur yang ditemukan pada bagian tubuh tukik penyu lekang (Lepidochelys olivacea) seperti leher, kaki, mata dan karapas dan cangkang telur penyu gagal menetas. 


\section{MATERI DAN METODE}

Materi yang digunakan dalam penelitian ini adalah penyu lekang (Lepoidochelys olivacea) yang berusia 10-14 hari dan terinfeksi jamur dari bagian tubuh tukik penyu lekang serta cangkang telur penyu lekang yang gagal menetas di TCEC Bali. Jamur kemudian di identifikasi di Laboratorium Bioteknologi Laut Tropis (Laboratorium Terpadu), Universitas Diponegoro, semarang. Media yang digunakan untuk kultur jamur adalah media standar PDA (Potato Dextrose Agar).

Penelitian ini menggunakan metode purposive sampling, penentuan sampel dengan mempertimbangkan kriteria-kriteria tertentu yang telah dibuat terhadap obyek yang sesuai dengan tujuan penelitian, hal tersebut sesuai dengan pernyataan Arikunto (2002). Data yang diperoleh dianalisa secara deskriptif. Metode deskriptif adalah suatu metode yang digunakan untuk menggambarkan atau menganalisis suatu hasil penelitian tetapi tidak digunakan untuk membuat kesimpulan yang lebih luas.

Hal pertama yang dilakukan sebelum pengambilan sampel yaitu dengan pemilihan tukik yang berusia 10-14 hari yang memiliki kriteria yang sesuai dan pisahkan dengan kolam yang berbeda. Pengambilan sampel dilakukan dengan menggunakan metode swabbing pada tukik penyu lekang dan cangkang telur yang gagal menetas pada pukul 8 pagi. Penggunaan metode ini dilakukan mengingat jamur yang tumbuh di permukaan (Fardiaz, 1989). Ambil jamur pada bagian karapas, leher, mata, kaki yang ditemukan infeksi jamur. Jamur yang sudah diambil kemudian diletakan ke dalam cawan petri berisi media PDA menggunakan cotton swab kemudian diinkubasi selama $5-7$ hari hingga didapatkan koloni murni.

Sampel jamur pada cangkang telur gagal menetas didapatkan 5 butir yang menurut penelitian Anwar (2014) ditemukan 10 butir telur yang gagal menetas di penangkaran Pariaman sedangkan di TCEC hanya ditemukan 5 butir telur penyu lekang yang gagal menetas. Kemudian sampel dimasukkan ke dalam kantong klip plastik. Pengisolasian jamur pada cangkang dilakukan dengan teknik penanaman pada media PDA. Fragmen cangkang telur terlebih dahulu di haluskan, kemudian diencerkan pada konsentrasi $20 \%$ dan $30 \%$. Untuk membuat konsentrasi $20 \%$ fragmen cangkang telur yang telah di haluskan ditimbang dengan berat $10 \mathrm{~g}$ dan dicampurkan aquades sebanyak $50 \mathrm{ml}$. Sedangkan untuk konsentrasi 30\% fragmen telur ditimbang sebanyak 3 gram dan dicampurkan dengan aquades sebanyak $10 \mathrm{ml}$. Setelah itu dengan menggunakan cotton swab masingmasing konsentrasi digores pada media PDA sebanyak 10 media dengan menggunakan teknik duplo.

\section{Identifikasi Jamur}

Tahap pertama yaitu pengamatan secara makroskopis yang meliputi pengamatan terhadap warna dan bentuk koloni. Tahap kedua yaitu pengamatan pada bentuk morfologi jamur seperti hifa, konidia, dan spora menggunakan mikroskopis pada perbesaran 400x. Seluruh hasil pengamatan selanjutnya dibandingakan dengan literatur untuk mengetahui identitas kapang tersebut (Ando, 1984; Gandjar et al., 1999).

\section{HASIL DAN PEMBAHASAN}

Sampel yang didapatkan diambil secara acak yang ditemukan pada bagian tubuh yang meliputi karapas, mata, kaki dan leher menggunakan metode swabbing. Pada gambar 1 terlihat jamur menginfeksi bagian karapasnya. Cangkang telur penyu lekang yang gagal menetas bisa dilihat dari warna cangkangnya yang lebih kuning agak kecoklatan. Selain itu apabila telur mengempis atau melunak seperti gambar dibawah ini menandakan bahwa telur gagal untuk berkembang. Hasil pengamatan gejala klinis dan identifikasi pada bagian tubuh penyu lekang yang terdapat pada leher, karapas, mata dan kaki bisa dilihat pada Tabel 1 dan 2 .

Jamur yang telah teridentifikasi dari tubuh tukik penyu lekang bagian karapas, leher, mata dan kaki yang memiliki bercak kuning dan putih pada bagian yang terinfeksi didapatkan 10 koloni jenis jamur yaitu Aspergillus sp, Fusarium sp, Phytophthora sp dan Trichoderma sp. Infeksi jamur ditemukan paling banyak pada bagian leher dan masing - masing jamur ditemukan pada bagian leher. Selain itu jamur yang paling banyak ditemukan adalah Fusarium sp sebanyak 4 koloni. Trichoderma $s p$ hanya ditemukan 1 koloni dari bagian leher di tubuh tukik penyu lekang 
(Lepidochelys olivacea). Hasil pengamatan dan identifikasi cangkang telur penyu lekang yang gagal menetas bisa dilihat pada Tabel 3 dan 4.

Jamur yang teridentifikasi dari cangkang telur penyu lekang yang gagal menetas dan cangkang yang melunak didapatkan sebanyak 4 koloni yang dapat di indentifikasi yaitu 2 koloni Aspergillus sp, 1 koloni Fusarium sp, dan 1 koloni Phytophthora sp. Satu koloni tidak dapat diidentifikasi karena jamur tidak tumbuh. Jenis jamur yang paling banyak ditemukan yaitu jamur Aspergillus sp yang masing - masing memiliki bercak kuning pada cangkang telur. Selain dari cangkang telur yang memiliki bercak kuning didapatkan juga dari cangkang telur yang melunak. Pada bagian tubuh tukik penyu lekang (Lepidochelys olivacea) telah didapatkan isolasi jamur sebanyak 10 koloni yang berasal dari karapas, mata, kaki, dan leher. Dari 10 koloni jamur yang telah teridentifikasi didapatkan 3 macam jenis jamur yang termasuk kedalam kategori genus jamur patogen yaitu, Aspergillus sp, Fusarium sp, dan Phytophthora sp. Selain itu didapatkan pula jamur Trichoderma $s p$ yang termasuk kedalam kategori jamur antagonis yang mampu mengendalikan jamur patogen seperti Fusarium sp. Jamur yang paling banyak ditemukan pada bagian tubuh tukik penyu lekang ( $L$. olivacea) yaitu Fusarium $s p$ dan penemuan infeksi jamur paling banyak yang menyerang tubuh tukik penyu lekang yaitu pada leher. Hal ini dikarenakan leher menjadi tempat berkumpulnya penyakit seperti jamur dan bakteri yang mampu menyerang langsung sel - sel tubuh (Leong et al., 1989).

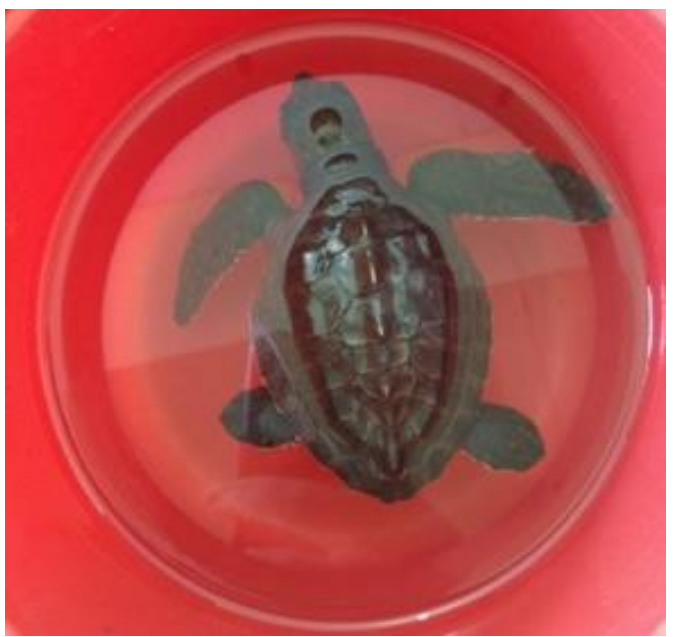

Gambar 1. Sampel penyu lekang yang terinfeksi jamur

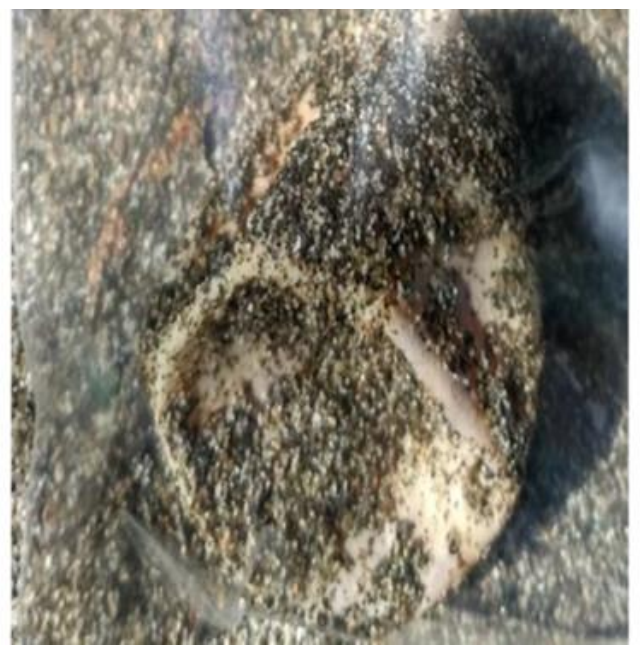

Gambar 2. Sampel cangkang telur penyu lekang gagal menetas memiliki kriteria seperti cangkang yang melunak dan mengempis 
Tabel 1. Pengamatan Gejala Klinis dan Hasil Identifikasi pada Bagian Tubuh Tukik Penyu Lekang (Lepidochelys olivacea)

\begin{tabular}{|c|c|c|c|}
\hline Gejala Klinis & Sampel Ke- & Hasil Isolasi (Morfologi) & Hasil Identifikas \\
\hline \multirow{4}{*}{ Leher } & 1 & $\begin{array}{l}\text { Koloni berwarna hijau tua, tekstur } \\
\text { kasar dan menonjol }\end{array}$ & Aspergillus sp \\
\hline & 2 & $\begin{array}{l}\text { Koloni berwarna krem berupa } \\
\text { kapas }\end{array}$ & Fusarium sp \\
\hline & 3 & $\begin{array}{l}\text { Koloni berwarna hijau memiliki } \\
\text { tekstur kasar }\end{array}$ & Trichoderma sp \\
\hline & 6 & Koloni berwarna putih krem & Phytophthora sp \\
\hline Karapas & 4 & $\begin{array}{l}\text { Koloni berwarna putih berupa } \\
\text { kapas }\end{array}$ & Fusarium sp \\
\hline Mata & $\begin{array}{c}7 \\
8 \\
10\end{array}$ & $\begin{array}{l}\text { Koloni berwarna putih } \\
\text { Koloni tumbuh berupa kapas } \\
\text { Koloni berwarna hijau kekuningan }\end{array}$ & $\begin{array}{l}\text { Fusarium sp } \\
\text { Aspergillus sp } \\
\text { Aspergillus sp }\end{array}$ \\
\hline Kaki & 9 & $\begin{array}{l}\text { Koloni berwarna kuning memiliki } \\
\text { tekstur kasar } \\
\text { Koloni berwarna putih krem berupa } \\
\text { beludru }\end{array}$ & Phytophthora sp \\
\hline
\end{tabular}

Tabel 2. Hasil Identifikasi Jamur pada Tubuh Tukik Penyu Lekang Bagian Karapas, Leher, Mata, Kaki

\begin{tabular}{ccccccc}
\hline \multirow{2}{*}{ No } & Jenis Jamur & \multicolumn{2}{c}{ Jumlah Sampel Teridentifikasi (koloni) } & \multicolumn{2}{c}{$\begin{array}{c}\text { Persentase Jamur yang } \\
\text { Teridentifikasi (\%) }\end{array}$} \\
\cline { 3 - 5 } & & karapas & leher & mata & kaki & \\
\hline 1 & Aspergillus $s p$ & - & 1 & 2 & - & $30 \%$ \\
2 & Fusarium $s p$ & 2 & 1 & - & 1 & $40 \%$ \\
3 & Phytophthora $s p$ & - & 1 & - & 1 & $20 \%$ \\
4 & Trichoderma $s p$ & - & 1 & - & - & $10 \%$ \\
\hline & Jumlah & 2 & 4 & 2 & 2 & $100 \%$ \\
\hline
\end{tabular}

Tabel 3. Pengamatan Cangkang Telur Gagal Menetas dan Hasil Identifikasi

\begin{tabular}{lcll}
\hline \multicolumn{1}{c}{$\begin{array}{c}\text { Ciri-ciri Cangkang } \\
\text { Telur }\end{array}$} & Sampel Ke- & \multicolumn{1}{c}{ Hasil Isolasi (Morfologi) } & Hasil ldentifikasi \\
\hline $\begin{array}{l}\text { Bercak kuning pada } \\
\text { cangkang }\end{array}$ & 1 & $\begin{array}{l}\text { Tidak tumbuh } \\
\text { Koloni berwarna hijau } \\
\text { kehitaman/abu-abu bertekstur } \\
\text { kasar } \\
\text { Koloni berwarna kuning pekat }\end{array}$ & Aspergillus sp \\
Cangkang telur lunak & 3 & $\begin{array}{l}\text { Koloni berwarna putih berupa } \\
\text { kapas } \\
\text { Koloni berwarna kuning dan } \\
\text { putih }\end{array}$ & Fusarium sp \\
\hline
\end{tabular}

Pada cangkang telur penyu lekang yang gagal menetas didapatkan 5 koloni jamur yang termasuk kategori jamur patogen yaitu Aspergillus sp, Fusarium sp, dan Phytophthora sp. Ketiga jamur patogen tersebut diambil dari cangkang telur yang memiliki bercak warna kuning, bentuk 
cangkangnya mengempis dan saat dipegang akan melunak. Jamur dibawa dari masa proses perkembangan embrio karena jamur tersebut dapat tumbuh pada suhu yang hangat dan dari busuknya materi tanaman yang mengendap di pasir peneluran. Jamur sendiri mampu menurunkan kadar kalsium dalam cangkang penyu, memudahkan penetrasi hifa dan akhirnya mempengaruhi embrio (Phillot et al. 2006).

Fusarium sp dan Aspergillus sp merupakan jamur yang menghasilkan senyawa mycotoxic yang mengganggu perkembangan embrio sehingga berkontribusi terhadap kegagalan telur penyu menetas. Jamur yang berkembang pada telur penyu mempengaruhi embrio denngan tiga cara antara lain: (1) menghambat pertukaran gas pada embrio, (2) penipisan kalsium pada cangkang telur sehingga mempengaruhi perkembangan embrio, (3) transfer spora jamur dari allantois ke jaringan embrio (Elshafie, et al, 2007). Penghambatan pertukaran gas oleh jamur dilakukan dengan menutup pori-pori kulit sehingg menyebabkan kematian. Namun, hal tersebut tergantung dari presentase kulit telur yang tertutupi jamur (Phillot dan Parmenter, 2001).

Phytophothora sp yang tergolong kedalam kelas Oomycetes dikatakan jamur tular tanah fitopatogenik yang dapat menginfeksi. Bisa dikatakan tumbuhnya jamur Phytophothora sp disebabkan dari telur saat diinkubasi dan pertumbuhannya lebih cepat saat penyu sudah terkena air dari kolam karena jamur ini termasuk kedalam jenis jamur air.

Faktor munculnya jamur pada telur dapat disebabkan oleh suhu, kelembaban lingkungan dan nutrisi yang terdapat pada lingkungan. Selain dikarenakan oleh lingkungan, adapun faktor lain adanya jamur pada saluran reproduksi induk penyu yang terinfeksi jamur (Reina, 2012).

Tabel 4. Hasil Identifikasi Jamur pada Cangkang Telur Penyu Lekang yang Gagal Menetas

\begin{tabular}{cccc}
\hline No & Jenis Jamur & Jumlah Sampel Teridentifikasi (koloni) & $\begin{array}{c}\text { Persentase Jamur yang } \\
\text { Teridentifikasi (\%) }\end{array}$ \\
\hline 1 & Aspergillus $s p$ & 2 & $40 \%$ \\
2 & Fusarium $s p$ & 1 & $20 \%$ \\
3 & Phytophthora $s p$ & 1 & $20 \%$ \\
4 & Trichoderma $s p$ & - & - \\
\hline & Jumlah & 4 & $80 \%$ \\
\hline
\end{tabular}

\section{Aspergillus sp.}

Berdasarkan pengamatan yang dilakukan secara makroskopis dan mikroskopis pada isolat ke 1, 8, 10 dari bagian tubuh tukik penyu lekang dan isolat ke 2 dan 3 dari cangkang telur penyu lekang yang gagal menetas merupakan genus Aspergillus sp. Dilihat secara makroskopis (Gambar 3) isolat didapatkan koloni berwarna hijau, teksturnya berupa granula kecil dan merata. Untuk isolat lainnya berwarna putih dan kuning pekat serta teksturnya dominan memiliki tekstur kasar dan ada juga yang halus. Sedangkan jika dilihat pada mikroskopis terdapat ciri utama dari genus Aspergillus $s p$ adalah metula dan fialidnya membentuk seperti bunga/kipas yang menempel dari vesikel serta konidianya yang tersebar berbentuk bulat dan semi bulat (Sibero et al., 2017).

Kepala konodia adalah struktur yang terletak di bagian terminal konidiofor, berbentuk bulat (globose) atau semibulat (subglobose) tersusun atas vesikel, metula (jika ada), fialid dan konidia. Vesikel adalah pembesaran konidiofor pada bagian apeksnya membentuk suatu struktur berbentuk globose, hemisferis, elips atau clavate. Konidiofor merupakan suatu struktur tegak lurus yang muncul dari sel kaki dan pada ujungnya menghasilkan kepala konidia. Sebagian besar dari spesies Aspergillus sp memiliki konidiofor tidak bercabang yang masing-masing menghasilkan kepala konidia tunggal.

Aspergillus $s p$ dapat tumbuh dengan cepat pada media PDA maupun MEA yang memiliki suhu ruang dan membentuk koloni granular, memproduksi hifa aerial yang membawa struktur konidia yang khas yaitu konidiofora yang panjang dengan vesikel-vesikel terminal dimana fialid menghasilkan rantai konidia basipetal. Rentang suhu untuk pertumbuhan jamur Aspergillus $s p$ yaitu mulai dari suhu kecil dari $20^{\circ} \mathrm{C}$ dan optimum pada suhu $20^{\circ} \mathrm{C}-30^{\circ} \mathrm{C}$. Hal ini sesuai dengan 
hasil penelitian yang dilakukan. Aspergillus $s p$ termasuk jamur pathogen yang disebut Aspergillosis, beberapa diantaranya bersifat saprofit sebagaimana banyak ditemukan pada bahan pangan (Fardiaz, 1992). Toksin yang dihasilkan oleh Aspergillus sp berupa mikotoksin. Mikotoksin adalah senyawa hasil sekunder metabolisme jamur. Mikotoksin yang dihasilkan oleh Aspergillus sp lebih dikenal dengan aflatoxin, dapat menyerang sistem saraf pusat.

Mallo, et al. (2002), melaporkan bahwa Aspergillus sp telah diisolasi dari lesi kulit dan mikosis superfisial dari penyu tempayan. Spesies Aspergillus terutama A. flavus, A. niger, A. terreus, $A$. nidulas, $A$. fumigatus, dan $A$. ochraceus juga terisolasi dari telur gagal menetas pada penyu hijau, dan jamur tersebut memproduksi mikotoksin pada telur dan penyu yang akan mempengaruhi embrio dan berkontribusi terhadap kematian penyu (Elshafie et al., 2007).

\section{Fusarium sp}

Berdasarkan hasil penelitian didapatkan pada isolat 2, 4, 7, 9 dari bagian tubuh tukik penyu lekang dan isolat keeempat dari cangkang telur gagal menetas. Terlihat bahwa koloni jamur Fusarium sp, berwarna putih hingga kecoklatan dan memiliki tekstur berupa kapas atau beludru. Sesuai dengan koloni yang didapat pada isolat keempat yang memiliki warna putih dan bertekstur berupa kapas.

Dengan pembesaran 400x mendapatkan gambaran jamur Fusarium sp yang memperlihatkan mikrokonidia, makrokonodia dan konidiofor. Fusarium $s p$ terdiri atas makrokonidia yang dibentuk pada cabang lateral dari hifa, makrokonidia tersebut berbentuk sabit dengan kedua ujung meruncing. Isolat Fusarium sp yang memiliki warna putih dan bertekstur seperti kapas didapatkan dari bercak putih pada karapas. Isolat Fusarium $s p$ lainnya yang ditemukan pada karapas, leher dan kaki berupa bercak kuning dan putih. Selain itu Fusarium sp juga ditemukan dari cangkang telur penyu lekang yang gagal menetas dan memiliki warna putih dan bertekstur seperti kapas tipis. Jamur Fusarium sp merupakan salah satu jamur yang ditemukan pada sarang pasir telur penyu (Guclu et al., 2010; Sarmiento- Ramirez et al., 2010). Fusarium sp dilaporkan sebagai parasit pada penyu laut bagian kepala, leher dan kulit penyu Lepidochelys kempii $L$. (Leong et al., 1989).

Menurut Phillot dan Parmenter (2001) genus Fusarium sp ditemukan juga pada isolasi pasir sarang yang menetas, menandakan jamur ini hadir dalam pasir dan masuk kedalam sarang mempengaruhi inkubasi telur penyu. Fusarium sp merupakan jamur patogen yang diisolasi dari penyu sisik (Sison, 1990). Jamur ini menyebabkan penyakit atau mengganggu fungsi sel normal oleh racun atau memproduksi enzim yang dapat mengganggu atau merusak sel-sel dalam telur. Phillott dan Parmenter (2001) melaporkan bahwa genus Fusarium sp secara teratur telah diisolasi sebagai pathogen tanah yang menular pada bagian luar telur yang gagal menetas. Jamur menembus lapisan anorganik dan organic dari cangkang untuk memanfaatkan jaringan embrio sebagai sumber nutrisi (Phillott, 2002).

Telur-telur penyu yang gagal menetas dilaporkan oleh Shanker et al. (2003) bahwa telur terkontaminasi oleh jamur. Jamur hadir dari dalam pasir dan menginfeksi kulit telur dan menyerang telur-telur yang sehat selama proses inkubasi. Telur penyu busuk mempengaruhi telur-telur lainnya yang berada dalam kontak langsung telur sehat sehingga untuk tingkat keberhasilan penetasan sangat kecil. Selain itu, Phillot, et al (2001) menemukan Fusarium solani yang merupakan spesies dari Fusarium $s p$ yang telah diisolasi dari cangkang telur gagal menetas pada sarang penyu tempayan. Fusarium saloni merupakan mycobiota umum pada tanah. Diantara jenis jamur yang diisolasi dari telur penyu tempayan di pantai Yaniklar, Fusarium sp paling sering terlihat dengan presentase $53,71 \%$. Umumnya Fusarium sp ditemukan pada cangkang telur, hal ini tidak menutup kemungkinan Fusarium sp tumbuh pada saat setelah menetas dan menempel pada bagian tubuh tukik penyu lekang. Fusarium sp yang ditemukan pada bagian tubuh tukik penyu lekang memiliki jumlah terbanyak yaitu berjumlah 4 koloni dibandingkan jenis jamur lainnya seperti Aspergillus sp dan Phytophthora sp. Pada cangkang telur penyu lekang yang gagal menetas juga ditemukan 1 koloni jamur Fusarium $s p$ yaitu pada cangkang telur yang melunak dan mengempis. 

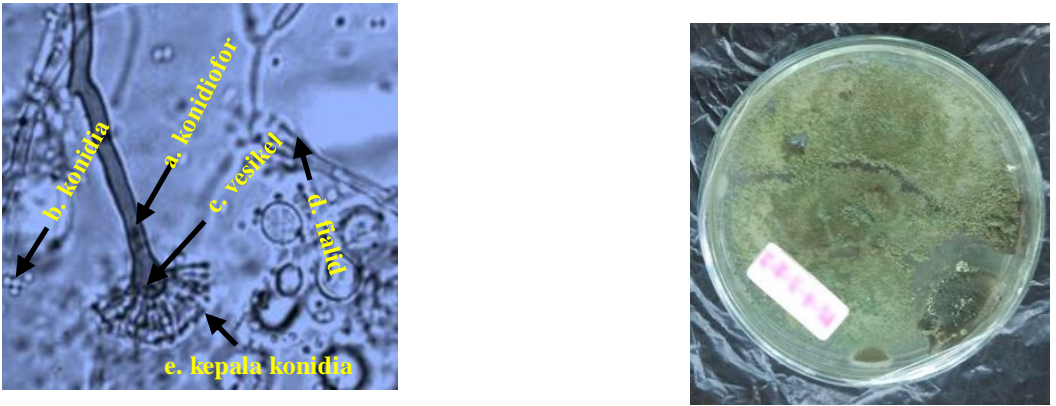

Gambar 3. Aspergillus sp
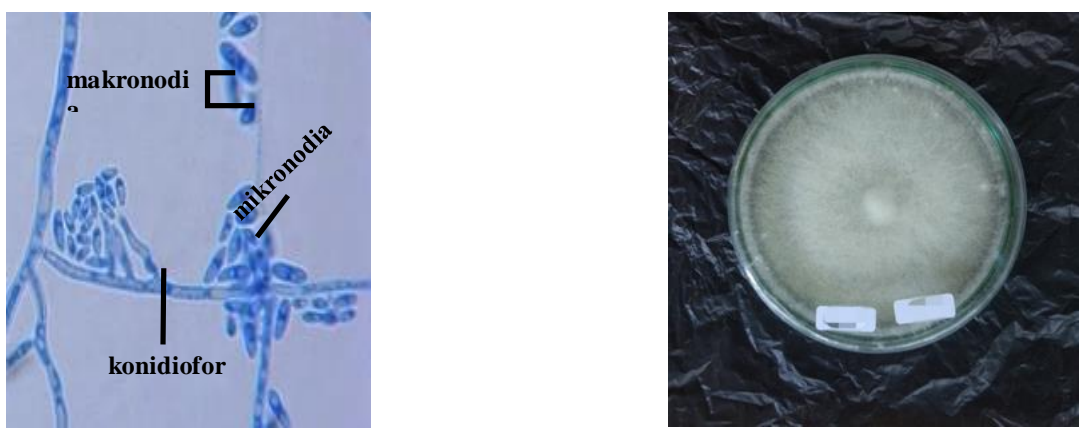

Gambar 4. Fusarium $s p$

\section{Phytophthora sp.}

Telah teridentifikasi 3 isolat yang termasuk kedalam genus Phytophthora sp. Masing-masing koloni berasal dari sampel cangkang telur yang gagal menetas (isolat 15) dan juga berasal dari karapas penyu lekang (isolat 5 dan isolat 6). Koloni yang ditemukan berwarna krem dan kuning dan permukaan kasar seperti tepung dan dibawahnya terdapat warna putih seperti kapas.

Pertumbuhan Phytophthora sp dikatakan lambat dikarenakan berbentuk bulat dengan tepi tidak rata, seperti kapas, berwarna putih, jika dipotong-potong menggunakan scalpel terasa agak kenyal. Phytophthora sp pada umumnya dapat tumbuh baik pada media agar PDA dan V8 dengan bentuk koloni stelat, dan atau tidak beraturan, bentuk permukaan miselium datar dan seperti kapas.

Hifanya tidak bersepta, reproduksi seksual dengan zoospora biflagela, organ seksualnya antheridia dan oogonia. Sporangiofor biasanya tidak dibedakan dengan miselium. Sporangia berbentuk ovoid, seperti lemon, memiliki papila. Adanya papila menjadi ciri khas Phytopthtora $s p$ yang dapat membedakannya dengan Phytium sp. yang tidak memiliki papilla.

Berdasarkan penelitian, ditemukannya Phytophthora $s p$ pada bagian tubuh penyu pada 2 isolat dibandingkan pada cangkangnya. Hal ini terjadi akibat adanya pencemaran melalui air pada kolam dikarenakan Phytophthora sp yang termasuk kedalam divisi Oomycota atau disebut jamur air mampu tumbuh dengan lebih cepat dalam air. Maka dari itu Phytophthora sp lebih banyak ditemukan di kaki dan leher dan memiliki bercak berwarna kuning. Jamur ini dapat bertahan dalam tanah dan mengadakan infeksinya terutama melalui tanah dan disini dapat membentuk sporangium dan spora kembara. Jamur terutama dipencarkan oleh air hujan di atas permukaan tanah. Infeksi ke pangkal batang dibantu oleh adanya luka, misalnya yang disebabkan oleh alatalat pertanian. Di dalam kebun P. cactorum dapat terbawa oleh aliran air bersama-sama dengan tanah. Selain itu jamur dapat terangkut jauh karena terbawa oleh bibit (okulasi) dan tanah yang menyertai bibit ini. 


\section{Trichoderma sp.}

Berdasarkan hasil yang ditemukan didapatkan satu koloni yang termasuk kedalam genus Trichoderma $s p$ yaitu pada isolat 3 yang didapatkan dari bercak di leher yang terinfeksi jamur. Trichoderma $s p$ mempunyai koloni berwarna hijau, menyebar ke segala arah dan berkembang cepat pada media PDA. Permukaan koloni mendatar dan memiliki tekstur permukaan halus dan berbutir, margin koloni rata. Pada umur 3 hari pada saat koloni ditanam terdapat pusat berwarna putih, kuning, hijau muda dan hijau tua, hal ini dikatakan bahwa Trichoderma sp memiliki lingkaran konsentris. Trichoderma sp tidak mempuyai eksudat. Pengamatan mikroskopis menunjukkan konidia yang oval atau lebih cenderung ke bulat, hifa berbentuk pipih, miseliumnya bersekat dan bercabang-cabang membentuk seperti anyaman. Konidiofor bercabang dan pada ujungnya terdapat fialid yang dimana tumbuh sel menyerupai botol (Sibero et al., 2016).

Trichoderma $s p$ sebagai pengendali Fusarium sp yang menyerang tanaman layu. Hal ini karena Trichoderma sp mempunyai peluang tinggi untuk berkompetisi merebut tempat hidup dan sumber makanan lebih dulu, lebih cepat menembus dinding sel dan masuk ke dalam sel untuk mengambil zat makanan, serta menghasilkan antibiotik yang dapat membunuh sel cendawan patogen (Harman 1998; Herman 2001). Kelompok jamur Trichoderma mempunyai mekanisme antagonis kompetisi, antibiosis dan mikoparasit yang efektif menekan perkembangan patogen.
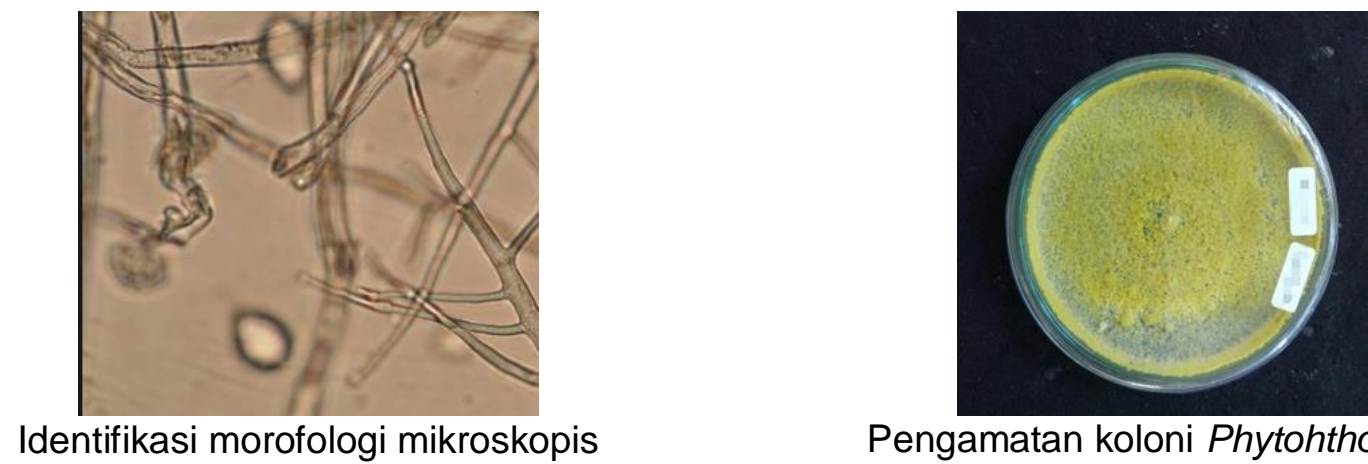

Pengamatan koloni Phytohthora sp

Gambar 5. Phytophthora sp

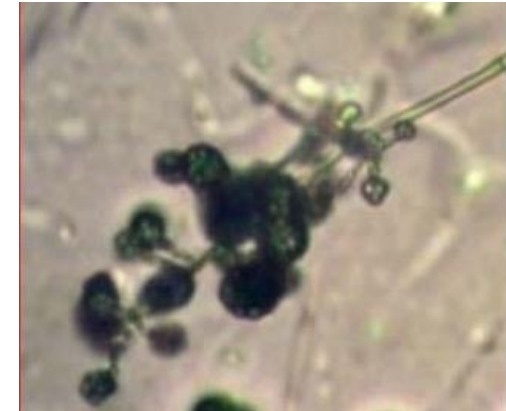

Identifikasi morofologi mikroskopis

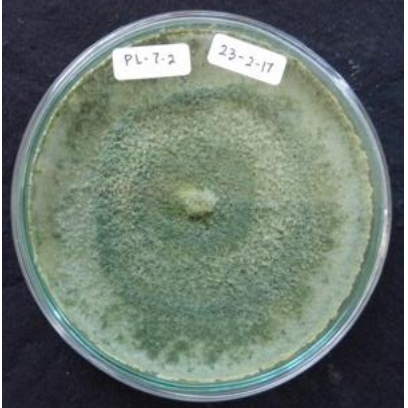

Pengamatan koloni Trichoderma sp

Gambar 6. Trichoderma sp

\section{KESIMPULAN}

Identifikasi jamur pada penyu lekang (Lepidochelys olivacea) yang didapat dari karapas, leher, mata dan kaki tukik penyu lekang serta pada cangkang telur penyu lekang yang gagal menetas Di TCEC Bali ditemukan jamur yang bersifat patogen yaitu Aspergillus sp, Fusarium sp, dan Phytopthora sp, serta jamur antagonis Trichoderma sp. Jamur yang paling banyak ditemukan pada bagian tubuh tukik penyu lekang yaitu berasal dari leher dan jamur yang paling banyak ditemukan yaitu Fusarium sp sebanyak 4 koloni. Pada cangkang telur penyu lekang yang gagal 
menetas yang dominan adalah Aspergillus sp sebanyak 2 koloni. Dari 15 sampel jamur yang telah diidentifikasi Aspergillus sp dan Fusarium sp memiliki jumlah yang sama yaitu 5 koloni serta hanya 1 sampel saja yang tidak tumbuh pada cangkang telur gagal menetas.

\section{DAFTAR PUSTAKA}

Ando, K. 1984. Identification of Mitosporic Fungi. Japan. Biological Resource Center, National Institute of Technology and Evaluation (NITE).

Anwar, S., Febria, F.A. \& Nasir, N. 2014. Identifikasi Koleksi Jamur dari Cangkang dan Pasir Sarang Telur Penyu Lekang (Lepidochelys olivacea L.) di Penangkaran Pariaman. Sumatera Barat. Jurnal Biologi Universitas Andalas, 3(1):46-50.

Arikunto, S. 2002. Prosedur Suatu Penelitian: Pendekatan Praktek. Edisi Revisi Kelima. Penerbit Rineka Cipta. Jakarta.

Elshafie, A, Al-Bahry, S.N., Alkindi, A.Y., Ba-Omar, T. \& Mahmoud, I. 2007. Mycoflora and Aflatoxins in Soil, Eggshells, and Failed Eggs of Chelonia mydas at Ras Al-Jinz, Oman. Chelonian Conserv. Biol. 6 (2):267-270.

Fardiaz, D. 1989. Analisa Pangan. Departemen Pendidikan dan Kebudayaan, Dirjen Pendidikan Tinggi PAU Pangan dan Gizi IPB. Bogor.

Fardiaz, S. 1992. Mikrobiologi Pangan 1. PT Gramedia Pustaka Umum. Jakarta.

Gandjar, I., Samson R.A., Tweel-Vermeulen, K., Oetari, A. \& Santoso, I. 1999. Pengenalan Kapang Tropik Umum. Jakarta. Yayasan Obor Indonesia.

Greiner, E.C. 2003. Coccidiosis in Reptiles. Seminar in Avian and Exotic Pet Medicine.

Guclu, O., Biyik, H. \& Sahiner, A. 2010. Mycoflora Identified From Loggerhead Turtle (Caretta caretta) Egg Shells and Nest Sand at Fethiye Beach, Turkey. African Journal of Microbiology Research. 4(5):408-413.

Harman, G.E. 1998. Trichoderma spp. Proc. Am. Acad. Sci. USA

Harman, G.E. 2001. Trichoderma spp., Including T. harzianum, T. viride, T. koningii, T. hamatum and Other spp. Deuteromycetes, Moniliales (asexual classification system. Cornell University, Geneva.

Higgins. 2003. Sea Turtle Husbandry. In Lutz, P.L., J.A. Musick. \& J. Wyneken. The Biology of Sea Turtles Vol II. CRC Press. 411- 440.

Javier, D.U., Jullie, M., Ramírez, S., Elena A., Martín, M.P., Tellería, M.T., Jurado L.F.L \& Marco, A. 2010. Fusarium solani is Responsible for Mass Mortalities in Nests of Loggerhead Sea Turtle, Caretta caretta, in Boavista, Cape Verde. FEMS Microbiology Letters; 312(2):192 DOI: 10.1111/j.1574-6968.2010.02116.x

Leong, J.K., Smith, D.L., Revara, Clary, D.B., Lewis, J.C., Scott, D.H. \& Di Nuzzo, J.L. 1989. Health Care and Diseases Of Captive-Reared Loggerhead and Kemp's Ridley Sea Turtles. In: Cailouet, C.W. (Eds.), Proceedings of the 1 st Internasional Symposium on Kemp's Ridley Sea Turtle, Conservation and Management. Texas.

Mallo, K., Craig, A.H., Gregory, A.L. \& Mark, G.P. 2002. Pharmacokinetics of Fluconazole in Loggerhead Sea Turtles (Caretta caretta) After Single Intravenous and Subcutaneous Injections, and Multiple Subcutaneous Injections. Journal of Zoo and Wildlife Medicine 33(1):29-35.

Phillot, A.D. \& Parmenter C.J. 2001. The Distribution of Failed Egg in Green (Chelonia mydas) and Loggerhand (Caretta caretta) Sea Turtle Nests and The Subsequent Appearance Of Fung. Australian Journal of Zoology.

Phillott, A.D., Parmenter, C.J., Limpus, C.J. \& Harrower, K.M., 2002. Mycobiota as acute and chronic cloacal contaminants of female sea turtles. Australian Journal of Zoology, 50(6):687695.

Phillott, A.D., Parmenter, C.J. and McKillup, S.C., 2006. Calcium depletion of eggshell after fungal invasion of sea turtle eggs. Chelonian Conservation and Biology, 5(1):146-149.

Reina, R.D., dan Rafferty, A.R. 2012. Arrested Embryonic Development: A Review of Strategies to Delay Hatching in Egg-Laying Reptiles. Procedings of the Royal Society B: Biological Sciences. 279: 2299-2308. 
Sarmiento-Ramirez, J. M., Abella, E., Martin, M. P., Telleria, M. T., Lopez-Jurado, L., Marco, A., Dieguez-Uribeondo, J. 2010. Fusarium solani is responsible for mass mortalities in nests of loggerhead sea turtle, Caretta caretta, in Boavista, Cape Verde. FEMS Microbiology Letters 312(2):192-200.

Shanker, K., Pandav B., dan Choudhury, B.C. 2003. An Assessment of The Olive Ridley Turtle (Lepidochelys olivacea) Nesting Population in Orissa, India. Biological Conservation. 115: 149-160.

Sibero, M. T., Triningsih, D. W., Radjasa, O. K., Sabdono, A. \& Trianto, A. 2016. Evaluation of Antimicrobial Activity and Identification of Yellow Pigmented Marine Sponge-Associated Fungi from Teluk Awur, Jepara, Central Java. Indonesian Journal of Biotechnology, 21(1):1-11.

Sibero, M. T., Sahara, R., Syafiqoh, N. \& Tarman, K. 2017. Antibacterial activity of red pigment isolated from coastal endophytic fungi against multidrug resistant bacteria. Biotropia 24(2):161-172

Sison, T.M, Padilla, M.A, Vizmanos, M.Z. \&Follosco, M. 1990. Isolation and Identification of Fungi in Necrotic Skin Lesions of Captive Marine Turtles (Eretmochelys imbricata). Philippine Journal of Veterinary Medicine. 27: 35-36. 